\title{
The Physicochemical and Thermal Properties of Consciousness Energy Healing Treated Silver Oxide $\left(\mathrm{Ag}_{2} \mathrm{O}\right)$
}

\author{
Gopal Nayak ${ }^{1}$, Mahendra Kumar Trivedi ${ }^{1}$, Alice Branton ${ }^{1}$, Dahryn Trivedi ${ }^{1}$ and Snehasis Jana ${ }^{2 *}$ \\ ${ }^{1}$ Trivedi Global, Inc., USA \\ ${ }^{2}$ Trivedi Science Research Laboratory Pvt Ltd, India
}

*Corresponding author: Snehasis Jana, Trivedi Science Research Laboratory Pvt Ltd, Bhopal, India

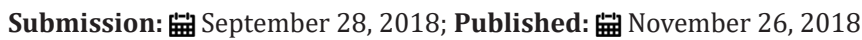

\begin{abstract}
Silver oxide possesses antimicrobial properties and also has numerous applications in space research, chemical, and pharmaceutical industries. It is not readily soluble in most of the solvents and highly sensitive to light. Thus, this study was executed to evaluate the impact of the Trivedi Effect ${ }^{\circledR}$-Consciousness Energy Healing Treatment on the physicochemical and thermal properties of silver oxide using PSA, PXRD, and DSC analytical techniques. The test sample was divided into two parts: one part was control sample and the other part was treated sample. The control sample did not receive Biofield Energy Treatment; whereas the treated sample received the Biofield Energy Treatment remotely by a renowned Biofield Energy Healer, Gopal Nayak. The particle size values of the treated silver oxide powder were significantly decreased at $d_{10}, d_{50}, d_{90}$, and $D(4,3)$ by $9.507 \%, 4.957 \%$, $3.463 \%$, and $4.787 \%$ respectively, thus the specific surface area was significantly increased by $7.647 \%$ compared with the control sample. The peak intensities and crystallite sizes were significantly altered from $-91.53 \%$ to $26.92 \%$ and $-69.76 \%$ to $8.83 \%$, respectively; however, the average crystallite size was significantly decreased by $35.62 \%$ in the treated sample compared with the control sample. The melting point and latent heat of fusion of the treated silver oxide were significantly increased by $2.47 \%$ and $538.57 \%$, respectively compared with the control sample. The results suggested that the Biofield Energy Healing Treatment might have introduced a new polymorphic form of silver oxide which would show better solubility, dissolution rate, absorption, bioavailability, and thermal stability. The treated silver oxide would be more efficacious as a medicine in the body and also advantageous for the pharmaceutical, space, chemical, nuclear submarine, optoelectronic industry when using it as a raw material.
\end{abstract}

Keywords: Silver oxide; Consciousness energy healing treatment; The Trivedi Effect ${ }^{\circledR}$; Complementary and alternative medicine; Particle size; Surface area; PXRD; DSC

\section{Introduction}

Silver oxide $\left(\mathrm{Ag}_{2} \mathrm{O}\right)$ is used as a laboratory reagent for the synthesis of other silver compounds, i.e., silver chloride, silver nitrate, etc. It is commonly used as a mild oxidizing agent for the oxidation of the organic compounds like aldehydes to carboxylic acids and also in the silver-oxide batteries. It is integrated into the fabrics used in surgery as it inhibits the growth of microbes [1-3]. It is also used in the concrete of the swimming pools and spas to protect the water from undesirable microbes. As it enhances the antimicrobial properties, it is also used as silver oxide ointment for difficult venous ulcerations, and even an essential component of the total wound dressing. It is improved microcirculation measurements and wound healing rate [4]. It helps removing carbon dioxide from the humidified air, which is helpful in the space missions (by the international space station, space shuttle, and nuclear submarines). Silver oxide is also used for the optoelectronic application and preparation of the pollution control filter for gas sensors, which absorbs airborne poisons and irritants $[5,6]$.

The physicochemical properties of silver oxide include; light sensitive, decomposes at lower temperatures, soluble in acid and alkali, slightly soluble in water, and insoluble in ethanol [1-3]. In the stability and application point of view, the physicochemical properties of any materials have a substantial role. In this point of view, the Trivedi Effect ${ }^{\circledR}$-Biofield Energy Healing Treatment has the significant impact on the physicochemical and thermal properties of various pharmaceutical and nutraceutical compounds [7-9]. The Trivedi Effect ${ }^{\circledR}$ is natural and the only scientifically proven phenomenon in which a person can harness this inherently intelligent energy from the Universe and transmit it anywhere on the planet through the possible mediation of neutrinos [10]. A unique para-dimensional electromagnetic field is generated around the body due to the continuous movement of the electrically charged particles, i.e., ions, cells, etc. inside the body of a living organism known as the "Biofield". The Biofield Energy Therapy has been accepted worldwide and reported with significant positive outcomes against various disease conditions [11]. The National Institutes of Health (NIH) and National Center for Complementary and Alternative Medicine (NCCAM) recommend and included the Energy Therapy under the Complementary and Alternative Medicine (CAM) along with Ayurvedic medicine, naturopathy, 
homeopathy, hypnotherapy, healing touch, yoga, Qi Gong, Tai Chi, deep breathing, etc. The Complementary and Alternative Medicine has been largely accepted by most of the U.S. people $[12,13]$. The Trivedi Effect ${ }^{\circledR}$-Consciousness Energy Healing Treatment is also a form of CAM, which shown significant impact in the alteration of the level of cytokines (IL- 6 and TNF- $\alpha$ ) in endometrium and prostate cancer cell lines [9]; altered the antimicrobial susceptibility, biochemical reactions pattern and biotype of microbes [10], altered the physicochemical properties, thermal properties, and isotopic abundance of metals, ceramics, and organic compounds [11-13], improved the productivity of crops [14], etc. The above facts motivated to design and to evaluate the impact of the Trivedi Effect $^{\circledR}$-Consciousness Energy Healing Treatment on the silver oxide powder using particle size analysis (PSA), powder X-ray diffraction (PXRD), and differential scanning calorimetry (DSC) analytical techniques.

\section{Materials and Methods}

\section{Chemicals and reagents}

The silver oxide powder sample was procured from Sigma Aldrich, India, whereas the other chemicals used during the experiments were of analytical grade also purchased in India.

\section{Consciousness energy healing treatment strategies}

The test sample of silver oxide powder was divided into two parts. The Trivedi Effect ${ }^{\circledR}$-Consciousness Energy Healing Treatment was received by one part of the test sample remotely under standard laboratory conditions for 3 minutes, known as the treated sample. The Biofield Energy Healing Treatment was provided through the healer's unique energy transmission process by a renowned Biofield Energy Healer, Gopal Nayak, India, to one part of the test sample. Accordingly, the other part of the test sample did not receive the Biofield Energy Treatment but treated with a "sham" healer and was known as a control sample. Though, the sham healer did not have any knowledge about the Biofield Energy Treatment. After treatment, the Biofield Energy Treated and control silver oxide powder samples were kept in sealed conditions and characterized using PSA, PXRD, and DSC analytical techniques.

\section{Characterization}

Particle size analysis (PSA): The particle size analysis of silver oxide powder was performed on Malvern Mastersizer 2000, from the UK, using wet method $[15,16]$. The sample unit (Hydro MV) was filled with a dispersant medium (sunflower oil) and operated the stirrer at $2500 \mathrm{rpm}$. The PSA analysis of silver oxide was executed to obtain the average particle size distribution and the specific surface area $\left(\mathrm{m}^{2} / \mathrm{g}\right)$. The calculations were done by using software Mastersizer Ver. 5.54. The \% change in particle size (d) for silver oxide powder at below $10 \%$ level $\left(d_{10}\right), 50 \%$ level $\left(d_{50}\right), 90 \%$ level $\left(d_{90}\right)$, and $D(4,3)$ was calculated using the following equation 1 :

$$
\% \text { change in particle size }=\frac{\left[\mathrm{d}_{\text {Treated }}-\mathrm{d}_{\text {Control }}\right]}{\mathrm{d}_{\text {Control }}} \times 10
$$

Where $\mathrm{d}_{\text {Control }}$ and $\mathrm{d}_{\text {Treated }}$ are the particle size $(\mu \mathrm{m})$ for at below $10 \%$ level $\left(d_{10}\right), 50 \%$ level $\left(d_{50}\right)$, and $90 \%$ level $\left(d_{90}\right)$ of the control and the Biofield Energy Treated silver oxide samples, respectively.
The \% change in surface area (S) was calculated using the following equation 2 :

$\%$ change in surface area $=\frac{\left[\mathrm{S}_{\text {Treated }}-\mathrm{S}_{\text {Control }}\right]}{\mathrm{S}_{\text {Control }}} \times 100$

Where $S_{\text {Control }}$ and $S_{\text {Treated }}$ are the surface area of the control and the Biofield Energy Treated silver oxide, respectively.

Powder X-ray diffraction (PXRD) analysis: The PXRD analysis of silver oxide powder was performed with the help of Rigaku MiniFlex-II Desktop X-ray diffractometer (Japan) [17,18]. The average size of individual crystallites of silver oxide was calculated from PXRD data using the Scherrer's formula (3):

$$
G=k \lambda / \beta \cos \theta(3)
$$

Where $\mathrm{k}$ is the equipment constant (0.94), $\mathrm{G}$ is the crystallite size in $\mathrm{nm}, \lambda$ is the radiation wavelength $0.154056 \mathrm{~nm}$ for $\mathrm{K} \alpha 1$ emission), $\beta$ is the full-width at half maximum (FWHM), and $\theta$ is the Bragg angle [19]. The \% change in crystallite size $(G)$ of silver oxide was calculated using the following equation 4 :

$\%$ change in crystallite size $=\frac{\left[\mathrm{G}_{\text {Treated }}-\mathrm{G}_{\text {Control }}\right]}{\mathrm{G}_{\text {Control }}} \times 100$ (4)

Where $G_{\text {Control }}$ and $G_{\text {Treated }}$ are the crystallite size of the control and the Biofield Energy Treated silver oxide samples, respectively.

Differential scanning calorimetry (DSC): The DSC analysis of silver oxide was performed with the help of DSC Q200, TA instruments. A sample of $\sim 2 \mathrm{mg}$ was loaded to the aluminium sample pan at a heating rate of $10^{\circ} \mathrm{C} / \mathrm{min}$ from $30^{\circ} \mathrm{C}$ to $350^{\circ} \mathrm{C}$ $[15,16]$. The $\%$ change in melting point $(\mathrm{T})$ was calculated using the following equation 5 :

$\%$ change in melting point $=\frac{\left[\mathrm{T}_{\text {Treated }}-\mathrm{T}_{\text {Control }}\right]}{\mathrm{T}_{\text {Control }}} \times 100$

Where $\mathrm{T}_{\text {Control }}$ and $\mathrm{T}_{\text {Treated }}$ are the melting point of the control and the Biofield Energy Treated silver oxide samples, respectively. The $\%$ change in the latent heat of fusion $(\Delta \mathrm{H})$ was calculated using following equation 6 :

$\%$ change in latent heat of fusion $=\frac{\Delta \mathrm{H}_{\text {treated }}-\Delta \mathrm{H}_{\text {control }}}{\Delta \mathrm{H}_{\text {control }}} \times 100(6)$

Where $\Delta \mathrm{H}_{\text {Control }}$ and $\Delta \mathrm{H}_{\text {Treated }}$ are the latent heat of fusion of the control and the Biofield Energy Treated silver oxide samples, respectively.

\section{Results and Discussion}

\section{Particle size analysis (PSA)}

The particle size and surface area of the treated silver oxide were altered compared to the control sample (Table 1). The particle size values of the control sample at $d_{10,} d_{50}, d_{90}$, and D $(4,3)$ were $22.267 \mu \mathrm{m}, 44.822 \mu \mathrm{m}, 78.307 \mu \mathrm{m}$, and $47.715 \mu \mathrm{m}$, respectively. Similarly, the particle sizes of the treated sample at $d_{10}, d_{50}, d_{90^{\prime}}$ and D $(4,3)$ were $20.15 \mu \mathrm{m}, 42.6 \mu \mathrm{m}, 75.595 \mu \mathrm{m}$, and $45.413 \mu \mathrm{m}$, respectively. Therefore, the particle size values in the Biofield Energy Treated sample was significantly decreased by $9.507 \%$, $4.957 \%, 3.463 \%$, and $4.787 \%$ at $d_{10}, d_{50}, d_{90}$, and D $(4,3)$ respectively, compared to the control sample (Table 1). The specific surface area of the treated silver oxide $\left(0.183 \mathrm{~m}^{2} / \mathrm{g}\right)$ was significantly increased by $7.647 \%$ compared to the control sample $\left(0.17 \mathrm{~m}^{2} / \mathrm{g}\right)$. 
Table 1: Particle size distribution of the control and the Biofield Energy Treated silver oxide.

\begin{tabular}{|c|c|c|c|c|c|}
\hline Parameter & $\mathbf{d}_{\mathbf{1 0}}(\boldsymbol{\mu m})$ & $\mathbf{d}_{\mathbf{5 0}}(\boldsymbol{\mu m})$ & $\mathbf{d}_{\mathbf{9 0}}(\boldsymbol{\mu m})$ & $\mathbf{D}(\mathbf{4}, \mathbf{3})(\boldsymbol{\mu m})$ & $\mathbf{S S A}\left(\mathbf{m}^{2} / \mathbf{g}\right)$ \\
\hline Control & 22.267 & 44.822 & 78.307 & 47.715 & 0.17 \\
\hline Biofield Energy Treated & 20.15 & 42.6 & 75.595 & 45.431 & 0.183 \\
\hline Percent change* $\%)$ & -9.507 & -4.957 & -3.463 & -4.787 & 7.647 \\
\hline
\end{tabular}

$\mathrm{d}_{10^{\prime}} \mathrm{d}_{50^{\prime}}$ and $\mathrm{d}_{90}$ : particle diameter corresponding to $10 \%, 50 \%$, and $90 \%$ of the cumulative distribution, $\mathrm{D}(4,3)$ : the average massvolume diameter, and SSA: the specific surface area. *denotes the percentage change in the Particle size distribution of the Biofield Energy Treated sample with respect to the control sample.

The experimental results indicated that the Trivedi Effect ${ }^{\circledR}$ Consciousness Energy Healing Treatment might have imposed an external force for breaking the larger particle of the silver oxide into the smaller particle sizes, hence increased the surface area. The particle characteristics have the significant impact on the solubility, dissolution rate, absorption, bioavailability, and even the therapeutic efficacy of pharmaceutical and nutraceutical compounds [20,21]. Thus, the Biofield Energy Treated silver oxide would show enhanced therapeutic efficacy in pharmaceutical/ nutraceutical formulations and would be more beneficial for the other industries using it as a raw material for the manufacturing.

\section{Powder X-ray diffraction (PXRD) analysis}

The PXRD diffractogram of the control sample showed the peaks at Bragg's angle (20) $18.52^{\circ}, 32.65^{\circ}, 33.59^{\circ}, 37.87^{\circ}, 39.5^{\circ}$, $54.69^{\circ}, 65.19^{\circ}$, and $68.52^{\circ}$ (Figure 1). Similarly, the Biofield Energy Treated sample showed the peaks at Bragg's angle (20) $18.64^{\circ}$, $32.77^{\circ}, 33.72^{\circ}, 37.04^{\circ}, 39.8^{\circ}, 54.79^{\circ}, 65.31^{\circ}$, and $68.58^{\circ}$ in the diffractogram (Figure 1). The sharp peak in the diffractograms of both the control and Biofield Energy Treated samples Figure 1 indicated that both the samples were crystalline. The highest peak intensity showed at $2 \theta$ equal to $32.67^{\circ}$ in both the control and the Biofield Energy Treated sample Table 2, entry 2. The peak intensities of the Biofield Energy Treated silver oxide powder were significantly altered ranging from $-91.53 \%$ to $26.92 \%$ compared to the control sample (Table 2). Similarly, the crystallite sizes of the Biofield Energy Treated sample were significantly altered ranging from $-69.76 \%$ to $8.83 \%$ compared to the control sample (Table 2). Overall, the average crystallite size of the treated silver oxide powder $(360.13 \mathrm{~nm})$ was significantly decreased by $35.62 \%$ compared with the control sample (559.38nm) (Table 2). The results clearly indicated significant alterations in the peak intensities and crystallite sizes of the Biofield Energy Treated silver oxide powder sample over the control sample. The peak intensity of any diffraction face on the crystalline compound changes according to the crystal morphology [22], and alterations in the XRD pattern provide proof of polymorphic transitions [23,24]. The Biofield Energy Healing Treatment might have introduced a new polymorphic form of silver oxide via the mediation of neutrino oscillations [10]. Different polymorphic forms of a compound have the significant effects on their physicochemical properties, i.e., melting point, stability, and solubility $[25,26]$. Therefore, the Biofield Energy Treated silver oxide would be a better candidate when used to design novel pharmaceutical formulations and also useful for the other manufacturing industries as a raw material.

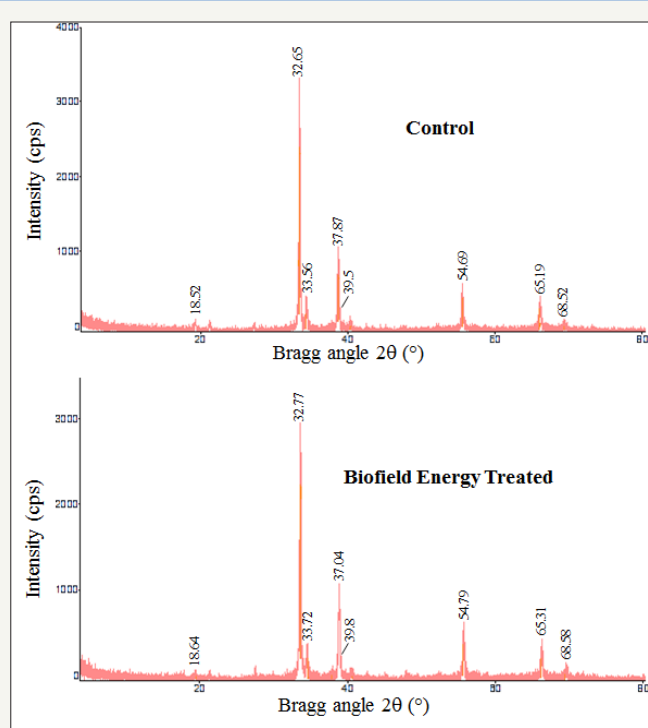

Figure 1: PXRD diffractograms of the control and the Biofield Energy Treated silver oxide. 
Table 2: PXRD data for the control and the Biofield Energy Treated silver oxide.

\begin{tabular}{|c|c|c|c|c|c|c|c|c|}
\hline \multirow[t]{2}{*}{ Entry No. } & \multicolumn{2}{|c|}{ Bragg angle $\left({ }^{\circ} 2 \theta\right)$} & \multicolumn{3}{|c|}{ Peak Intensity (\%) } & \multicolumn{3}{|c|}{ Crystallite size (G, nm) } \\
\hline & Control & Treated & Control & Treatd & $\%$ change $^{a}$ & Control & Treated & $\%$ change $^{b}$ \\
\hline 1 & 18.52 & 18.64 & 10.4 & 13.2 & 26.92 & 992 & 300 & -69.76 \\
\hline 2 & 32.65 & 32.77 & 536 & 548 & 2.24 & 588 & 532 & -9.52 \\
\hline 3 & 33.56 & 33.72 & 79 & 74 & -6.33 & 385 & 419 & 8.83 \\
\hline 4 & 37.87 & 37.04 & 189 & 16 & -91.53 & 525 & 221 & -57.9 \\
\hline 5 & 39.5 & 39.8 & 20.8 & 20 & -3.85 & 416 & 194 & -53.37 \\
\hline 6 & 54.69 & 54.79 & 121 & 124 & 2.48 & 515 & 454 & -11.84 \\
\hline 7 & 65.19 & 65.31 & 81 & 89 & 9.88 & 466 & 416 & -10.73 \\
\hline 8 & 68.52 & 68.58 & 20.1 & 21 & 4.48 & 588 & 345 & -41.33 \\
\hline 9 & \multicolumn{5}{|c|}{ Average crystallite size } & 559.38 & 360.13 & -35.62 \\
\hline
\end{tabular}

${ }^{a}$ denotes the percentage change in the peak intensity of the Biofield Energy Treated sample with respect to the control sample; bdenotes the percentage change in the crystallite size of Biofield Energy Treated sample with respect to the control sample

\section{Differential scanning calorimetry (DSC) analysis}

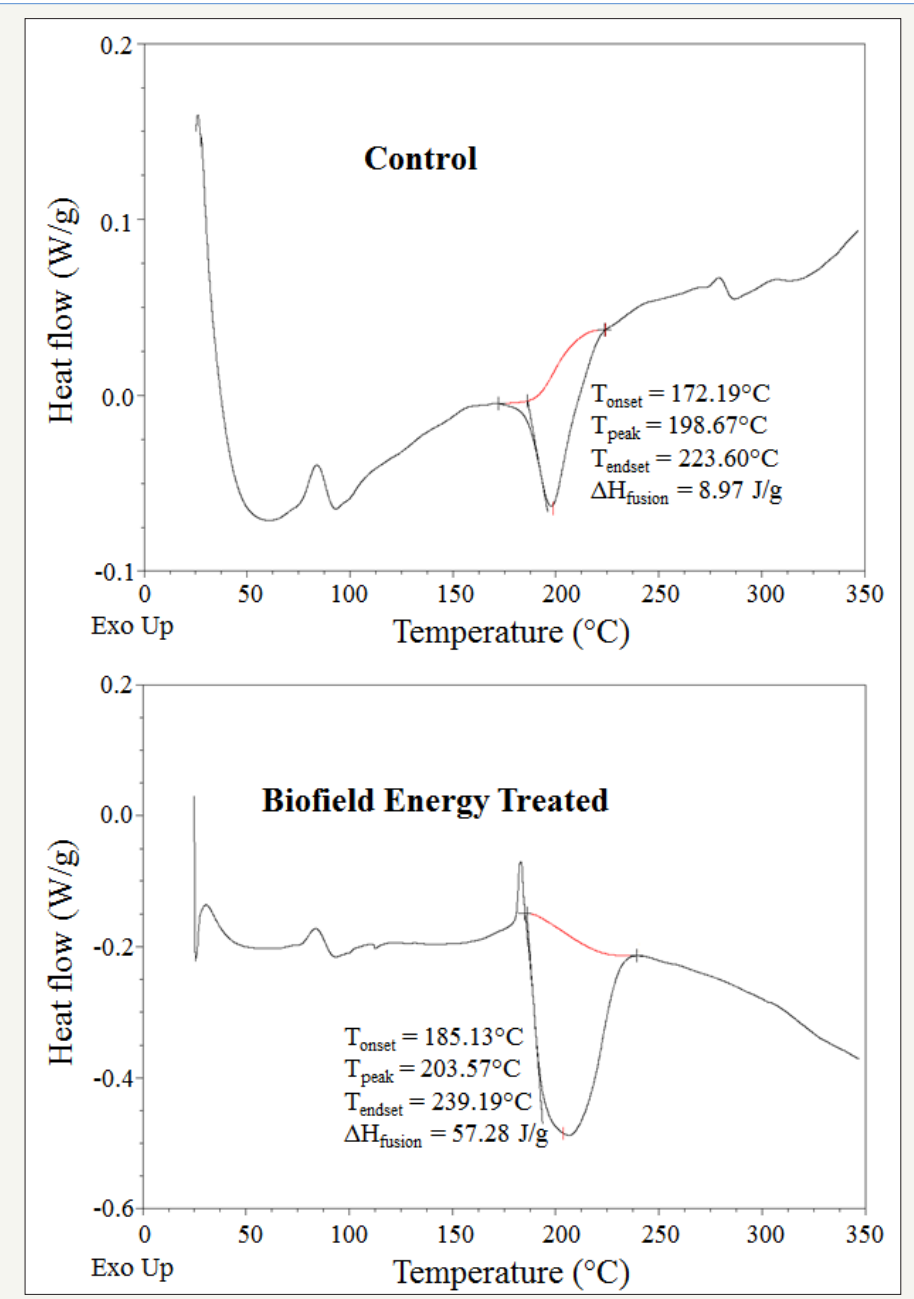

Figure 2: DSC thermograms of the control and the Biofield Energy Treated silver oxide.

The DSC thermograms of the control and the Biofield Energy data well matched with the reported literature [1]. The melting Treated silver oxide showed a sharp endothermic peak at $203.57^{\circ} \mathrm{C}$ point of the Biofield Energy Treated silver oxide sample was and $198.67^{\circ} \mathrm{C}$, respectively (Table 3 \& Figure 2). The experimental increased by $2.47 \%$ compared with the control sample (Table 3 ). 
The latent heat of fusion $\left(\Delta \mathrm{H}_{\text {fusion }}\right)$ of the treated silver oxide sample $(57.28 \mathrm{~J} / \mathrm{g})$ was significantly increased by $538.57 \%$ compared with the control sample (8.97J/g) (Table 3). Any intermolecular change in the compound structure has the significant effect on the latent heat of fusion [27]. Therefore, the Gopal Nayak's Biofield Energy Treatment might have altered the molecular chain strength and crystal structure of silver oxide. This could be the possible reason behind the significant improvement of the melting point, and latent heat of fusion of the Biofield Energy Treated silver oxide sample compared to the control sample.

Table 3: DSC data for both control and the Biofield Energy Treated samples of silver oxide.

\begin{tabular}{|c|c|c|}
\hline Sample & Melting point $\left({ }^{\circ} \mathbf{C}\right)$ & $\Delta \mathbf{H}(\mathbf{J} / \mathbf{g})$ \\
\hline Control sample & 198.67 & 8.97 \\
\hline Biofield Energy Treated & 203.57 & 57.28 \\
\hline \%Change* & 2.47 & 538.57 \\
\hline
\end{tabular}

$\Delta \mathrm{H}$ : Latent heat of fusion, *denotes the percentage change of the Biofield Energy Treated silver oxide with respect to the control sample.

\section{Conclusion}

The Trivedi Effect ${ }^{\circledR}$-Consciousness Energy Healing Treatment has a significant impact on the particle size, surface area, peak intensities, crystallite size, and thermal properties of silver oxide. The particle size values of the treated silver oxide powder were significantly decreased at $d_{10}, d_{50}, d_{90}$, and $D(4,3)$ by $9.507 \%$, $4.957 \%, 3.463 \%$, and $4.787 \%$, respectively, thus the specific surface area was significantly increased by $7.647 \%$ compared with the control sample. The peak intensities and crystallite sizes were significantly altered from $-91.53 \%$ to $26.92 \%$ and $-69.76 \%$ to $8.83 \%$, respectively; however, the average crystallite size was significantly decreased by $35.62 \%$ in the Biofield Energy Treated sample compared with the control sample. The melting point and latent heat of fusion of the Biofield Energy Treated silver oxide was significantly increased by $2.47 \%$ and $538.57 \%$, respectively compared with the control sample. It can be concluded that The Trivedi Effect ${ }^{\circledR}$-Consciousness Energy Healing Treatment might create a new polymorphic form of silver oxide which would show better solubility, dissolution rate, absorption, bioavailability, and thermal stability of silver oxide in the pharmaceutical preparations (i.e., ointments, wound dressing, etc.) and also advantageous for the pharmaceutical, space, chemical, nuclear submarine, optoelectronic industry when using it as a raw material.

\section{References}

1. Allahverdiyev AM, Abamor ES, Bagirova M, Rafailovich M (2011) Antimicrobial effects of $\mathrm{TiO}(2)$ and $\mathrm{Ag}(2) 0$ nanoparticles against drugresistant bacteria and leishmania parasites. Future Microbiol 6(8): 933940.

2. Akiyama T, Miyamoto H, Yonekura Y, Tsukamoto M, Ando Y, et al. (2013) Silver oxide-containing hydroxyapatite coating has in vivo antibacterial activity in the rat tibia. J Orthop Res 31(8):1195-1200.

3. https://saltlakemetals.com/msds_silver_oxide/
4. Belcaro G, Cesarone MR, Errichi BM, Ricci A, Antelman P, et al. (2011) Silver oxide ointment wound dressing in venous ulcerations: home, selfmanagement. Panminerva Med 53(3 suppl): 29-33.

5. http://www.creativepen.in/2014/01/uses-of-silver-oxide.html

6. Hassan MAM, Agool IR, Raoof LM (2014) Silver oxide nanostructure prepared on porous silicon for optoelectronic application. Applied Nanoscience 4(4): 429-447.

7. Trivedi MK, Patil S, Shettigar H, Singh R, Jana S, et al. (2015) An impact of biofield treatment on spectroscopic characterization of pharmaceutical compounds. Mod Chem appl 3: 159.

8. Trivedi MK, Branton A, Trivedi D, Nayak G, Lee AC, et al. (2017) An investigation of the Trivedi Effect ${ }^{\circledR}$-Energy of Consciousness Healing Treatment to modulate the immunomodulatory effect of herbomineral formulation in male Sprague Dawley rats. Advances in Materials 5: 144-153.

9. Trivedi MK, Patil S, Shettigar H, Gangwar M, Jana S (2015) In vitro evaluation of biofield treatment on cancer biomarkers involved in endometrial and prostate cancer cell lines. J Cancer Sci Ther 7: 253-257.

10. Trivedi MK, Patil S, Shettigar H, Mondal SC, Jana S (2015) In vitro evaluation of biofield treatment on Enterobacter cloacae: Impact on antimicrobial susceptibility and biotype. J Bacteriol Parasitol 6: 241.

11. Trivedi MK, Tallapragada RM (2008) A transcendental to changing metal powder characteristics. Metal Powder Report 63(9): 22-28.

12. Trivedi MK, Nayak G, Patil S, Tallapragada RM, Latiyal O (2015) Studies of the atomic and crystalline characteristics of ceramic oxide nano powders after bio field treatment. Ind Eng Manage 4: 161.

13. Trivedi MK, Branton A, Trivedi D, Nayak G, Panda P, et al. (2016) Mass spectrometric analysis of isotopic abundance ratio in biofield energy treated thymol. Frontiers in Applied Chemistry 1(1): 1-8.

14. Trivedi MK, Branton A, Trivedi D, Nayak G, Mondal SC, et al. (2015) Morphological characterization, quality, yield and DNA fingerprinting of biofield energy treated alphonso mango (Mangifera indica $L$ ) Journal of Food and Nutrition Sciences 3: 245-250.

15. Trivedi MK, Sethi KK, Panda P, Jana S (2017) A comprehensive physicochemical, thermal, and spectroscopic characterization of zinc (II) chloride using Xray diffraction, particle size distribution, differential scanning calorimetry, thermogravimetric analysis/ differential thermogravimetric analysis, ultravioletvisible, and Fourier transforminfrared spectroscopy. Int J Pharm Investig 7(1): 33-40.

16. Trivedi MK, Sethi KK, Panda P, Jana S (2017) Physicochemical, thermal and spectroscopic characterization of sodium selenate using XRD, PSD, DSC, TGA/DTG, UV-vis, and FT-IR. Marmara Pharmaceutical Journal 21(2): 311-318

17. Desktop X-ray Diffractometer MiniFlex+ (1997) The Rigaku Journal 14: 29-36.

18. Zhang T, Paluch K, Scalabrino G, Frankish N, Healy AM, et al. (2015) Molecular structure studies of (1S,2S)-2-benzyl-2,3-dihydro-2(1Hinden-2-yl)-1H-inden-1-ol. J Mol Struct 1083: 286-299.

19. Langford JI, Wilson AJC (1978) Scherrer after sixty years: A survey and some new results in the determination of crystallite size. J Appl Cryst 11: 102-113.

20. Khadka P, Ro J, Kim H, Kim I, Kim JT, et al. (2014) Pharmaceutical particle technologies: An approach to improve drug solubility, dissolution and bioavailability. Asian J Pharm Sci 9(6): 304-316.

21. Buckton G, Beezer AE (1992) The relationship between particle size and solubility. Int J Pharmaceutics 82(3): R7-R10.

22. Inoue M, Hirasawa I (2013) The relationship between crystal morphology and XRD peak intensity on $\mathrm{CaSO} 4.2 \mathrm{H}_{2} \mathrm{O}$. J Crystal Growth 380: $169-175$ 
23. Raza K, Kumar P, Ratan S, Malik R, Arora S (2014) Polymorphism: The phenomenon affecting the performance of drugs. SOJ Pharm Pharm Sci 1(2): 10 .

24. Brittain HG (2009) In: Polymorphism in pharmaceutical solids in Drugs and Pharmaceutical Sciences, ( $2^{\text {nd }}$ edn), Informa Healthcare USA, Inc New York, USA, Volume 192.

25. Censi R, Martino PD (2015) Polymorph impact on the bioavailability and stability of poorly soluble drugs. Molecules 20(10): 18759-18776.
26. Blagden N, Matas M, Gavan PT, York P (2007) Crystal engineering of active pharmaceutical ingredients to improve solubility and dissolution rates. Adv Drug Deliv Rev 59(7): 617-630.

27. Zhao Z, Xie M, Li Y, Chen A, Li G, et al. (2015) Formation of curcumin nanoparticles via solution-enhanced dispersion by supercritical $\mathrm{CO}_{2}$. Int J Nanomedicine 10: 3171-3181.

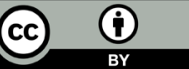

Creative Commons Attribution 4.0 International License

For possible submissions Click Here

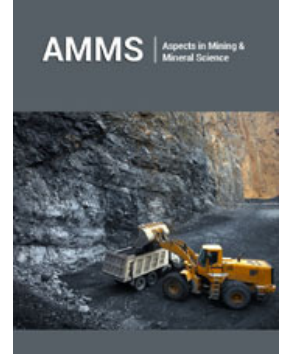

\section{Aspects in Mining \& Mineral Science}

\section{Benefits of Publishing with us}

- High-level peer review and editorial services

- Freely accessible online immediately upon publication

- Authors retain the copyright to their work

- Licensing it under a Creative Commons license

- Visibility through different online platforms 